\title{
Incorporating Migrant Farmers into Nigeria's Agricultural Extension Policy
}

\author{
Iwuchukwu, J.C, A. E. Agwu and E. M. Igbokwe \\ Department of Agricultural Extension \\ University of Nigeria, Nsukka \\ Enugu State, Nigeria \\ E-mails: julieiwuchukwu@yahoo.com; agwuekwe1@yahoo.com; emigbo@yahoo.com
}

\begin{abstract}
The paper described the rural dynamics of lgbo migrant farmers found among Odolu/lgalamela people of Kogi State of Nigeria. Semi-structured interview schedule were used in collecting data from one hundred heads of migrant households. Percentages, wealth classification, mean scores and T-test were used to analyze the data obtained. The study revealed that majority of the responden ts were poor farmers who migrated more than 11 years ago because of economic reasons and poor soils at source area. Most of the migrant farmers had strong links with their places of origin and returned more than twelve times in a year for burial ceremonies of relations, traditional festivals, meetings and marriages. Although both migrant men and women were engaged in various agricultural activities, there were significant differences in each of the various activities engaged in on the basis of gender. The study further revealed that agricultural extension has not made much contribution to the lives and agricultural production of these migrant farmers. There is therefore the need to enact agricultural extension policy that will incorporate these groups of farmers into the general clients targeted by the public extension service in the country.
\end{abstract}

Key words: Igbo migrant farmers, conflicts, gender, policy, extension services.

\section{INTRODUCTION}

Migration in Nigeria is associated with a series of social, cultural, political and more importantly economic factors. It involves a change in place of residence across a defined geopolitical boundary (NPC, 1998). Economic models view it primarily as a response to spatial earnings differentials (Okojie, 1984). The rural poor view it as the cause and effect of poverty (World Bank, 2000). It is one of the three major components of population change. Others are fertility and mortality. Out of the three, the most difficult to characterize and measure is migration (Bernard and Spencer, 1998). 
Migration to farming areas begins with scarcity of land at source area and establishment of farming locations in areas many miles away from the residence or place of origin of farmers (Grant, 1998). Communities experiencing food insecurity, fall in demand and low wages for labour due to infertile land, scarcity of land, poor climatic condition, lack of social infrastructure and extension service, as well as serious political and religious crisis will under normal circumstances move to communities with better prospects in order to survive. Thus, the concentration of farmers in a particular location for farming activities is purely on the basis of favourable resources (Grant, 1998).

The study of migration has in recent decades become more important in demography due to its impact on demographic, social and economic status of many countries at national, regional and district levels (Mkhwanazi et, al, 1993). Unfortunately migration data especially internal migration data are more difficult to collect because of the absence of internal regional boundaries in most countries. Even where such boundaries exist, very little data are collected (Mkhwanazi et. al, 1993). However, migration data are important because they provide information on the diverse origin of rural migrants, socio-economic attributes, adjustment processes, types of activities migrant engage in and their spatial distribution which are needed for regional planning in the country (Adepoju, 1986). This is because plans and policies formed based on these information will always ensure that the potentials of the rural migrants are judiciously harnessed in order to achieve development.

Policy makers in developing countries focus largely on rural-urban migration because of its visibility and impact on the cities where government resides. However, rural-rural migration is by far the major type of population movement and a fact that is often acknowledged only from a negative perspective in the context of environmental degradation (Dasgupta, 1984). Rural-rural migration is considerably varied and include at least two important categories, first the movement of rural agricultural labourers to more fertile areas in search of job opportunities, second the movement of farmers who are expelled from their lands by force or because of land shortage, poor soil or poor economic conditions and settle in other rural communities (F.A.O. 1998). These movements have impact on both origin and destination of these migrants and on agriculture but have attracted little or no attention. To buttress this fact Fadayomi (1988) noted that in the course of investigation, lesser attention has been paid to the consequences of migration on the sending and receiving communities and especially on the impact of government development policies on population distribution in these areas which have direct useful information for policy formulation, programming and evaluation.

In view of the above, this study sought to find out the rural dynamics of Igbo migrant farmers found among Odolu/lgalamela people of Kogi State of Nigeria, focusing on their reasons for migrating and existing linkages with source areas; agricultural activities of migrant men and women farmers in destination area, as well as, the existing contact between agricultural extension service and the migrants.

\section{METHODOLOGY}

The study was conducted in Odolu/Igalamela, a rural sub-ethnic region of Igala land bordering the North-western end of Enugu State. Five towns (Odolu, Akpanya, Avrugo, Ajaka, Ekwulu-Oko) were purposively selected for the study from the nine towns that make up Odolu/Igalamela ethnic region. This was because of high 
concentration of Igbo migrant households in these towns. From each of the selected towns, 20 households were purposively selected, hence 100 heads of households participated in the study. Structured interview schedule was used to collect relevant information.

The levels of participation of migrant men and women farmers in agricultural activities in the area were assessed using a four-point Likert-type scale with responses ranging from "not at all" to "very often" and scaled 0 to 3 respectively. Responses of the respondents were later categorized on the basis of gender according to mean scores. In this regard, activities with mean scores of 1.5 and above were regarded as activities in which men and/or women participated in actively.

Traditional method of wealth classification was used to determine the wealth status of the migrant farmers. Following the methodology of Poats and Feldstein (1990), the wealth status of each migrant farmer was computed by adding weightings of farm tools owned, number of different types of animals owned and type of housing. Values were assigned to farm tools as follows: File (1) rake (2) Sickle (3), shovels (4), digger (5), axe (6), pick axe (7), matchet (8) hoe (9) and barrow (10). Values assigned to animals were as follows: Rabbit (1), Chicken (2), sheep (3) and goat (4), while type of housing had the following values: hut (1), thatched and mud house (2) Mud house with zinc (3), Concrete house with zinc (4) and painted zinc/concrete house (5). The assigning of values to farm tools and animals was based on the value perception by the migrant farmers while that of housing was based on the value or quality of house. Respondents with wealth status ranging between 19 and 70 were classified as being very poor, $71-122$ were classified as being poor, $123-174$ were classified as being average $175-226$ were classified as being rich while 227 - 278 were classified as being very rich. Data were summarized using percentage, mean scores and $t$-test statistics.

\section{RESULTS AND DISCUSSION}

\section{Household Dynamics of the Igbo Migrants}

\section{Number of years spent at destination area}

Table 1 shows that the number of years the respondents had spent in the destination area ranged between 1 and 30 years. Forty-three percent of the respondents had spent $11-15$ years in the destination area, $17 \%$ of them had spent $21-25$ years, while $16 \%$ of them had spent $1-5$ years in the destination area. The mean number of years the respondents had spent in the destination area was 14.5 years.

\section{Intra-household migration decision making}

The decision to migrate to the present destination was taken by different members in the families of the respondents. Fifty six percent of the respondents migrated as a result of their father's decision to migrate, $21 \%$ of them migrated as a result of their parent's decision to migrate, while $12 \%$ of them migrated as a result of the decision of other relations at the destination area. Also $7 \%$ of the respondents migrated as a result of the decision of the relations at source area while the remaining $4 \%$ migrated as a result of the family decision to migrate. This finding supports the fact that decisions about movement of the migrant may or may not coincide with the wishes or interests of the individuals who moves (UN, 1995), and that relations/friends 
in the destination area exert strong influence on the decision to migrate because they provide succour to the new arrival and help them adjust in the new environment (Ekong, 1988).

\section{Reasons for Migration}

Majority $(76 \%)$ of the respondents migrated because of economic reasons, $54 \%$ of them migrated because of poor soils at source area, $23 \%$ of them migrated because of settlement of close relations in the destination area, while $19 \%$ of them migrated because of lack of land (Table 1). The findings tend to show that most ruralrural migration acts are spurred by the lack of access to resources especially farmland and the search for fertile land where food security is assured.

\section{Existing Linkages with Source Areas}

Table 1 further shows that majority (64\%) of the respondents returned to their place of origin more than 12 times in a year. Also $14 \%$ of the respondents returned 4 -6 times in a year and $10 \%$ of them returned $7-9$ times in a year. The regularity of the returns indicates that the migrants maintain strong links with their source areas.

The respondents had different reasons for returning to the place of origin. Majority (94\%) of the respondents returned to place of origin because of death of relations, $91 \%$ of them returned to place of origin to celebrate festivals, $81 \%$ returned to attend meetings while $72 \%$ of them returned because of marriages. The frequency of return migration can strengthen migration linkages between these two areas which may, create channels for further movement of people and operate as an important conduit of information, money and goods in both directions (Hugo, 1998). This will depend however, on the opening up of the area in terms of physical infrastructure. 
TABLE 1: Distribution of Igbo migrants based on household dynamics

\begin{tabular}{|c|c|c|c|}
\hline \multicolumn{4}{|l|}{ Household dyanamics } \\
\hline $\begin{array}{l}\text { Number of years spent at destination } \\
\text { area }\end{array}$ & Frequency & Percentage & Mean $\bar{X}$ \\
\hline $1-5$ & 16 & 16 & \\
\hline $6-10$ & 5 & 5 & 14.5 \\
\hline $11-15$ & 43 & 43 & \\
\hline $16-20$ & 12 & 12 & \\
\hline $21-25$ & 17 & 17 & \\
\hline $26-30$ & 7 & 7 & \\
\hline \multicolumn{4}{|l|}{$\begin{array}{l}\text { Intra-household migration decisions } \\
\text { making }\end{array}$} \\
\hline Father & 56 & 56 & \\
\hline Parents & 21 & 21 & \\
\hline Whole family & 4 & 4 & \\
\hline Relations at source area & 7 & 7 & \\
\hline Relations at distraction area & 12 & 12 & \\
\hline \multicolumn{4}{|l|}{ Reasons for migration } \\
\hline Economic reasons & 76 & 76 & \\
\hline Poor soils at source area & 54 & 54 & \\
\hline $\begin{array}{l}\text { Settlement of close relations in the } \\
\text { destination area }\end{array}$ & 23 & 23 & \\
\hline Lack of land & 19 & 19 & \\
\hline To farm and get enough food & 13 & 13 & \\
\hline $\begin{array}{l}\text { Settlement of friends in the destination } \\
\text { area }\end{array}$ & 2 & 2 & \\
\hline To get labour & 1 & 1 & \\
\hline \multicolumn{4}{|l|}{ Number of times returned } \\
\hline $1-3$ & 8 & 8 & \\
\hline $4-6$ & 14 & 14 & \\
\hline $7-9$ & 10 & 10 & \\
\hline $\begin{array}{l}10-12 \\
>12\end{array}$ & 4 & 4 & \\
\hline Reasons for the returns* & 64 & 64 & \\
\hline Death of relations & 94 & 94 & \\
\hline Festivals & 91 & 91 & \\
\hline Marriages & 72 & 72 & \\
\hline Rest & 37 & 37 & \\
\hline Meetings & 81 & 81 & \\
\hline Seek labour & 22 & 22 & \\
\hline Illness & 48 & 48 & \\
\hline See family members and relations & 33 & 33 & \\
\hline Execute projects & 20 & 20 & \\
\hline Political interaction & 8 & 8 & \\
\hline
\end{tabular}

*Multiple responses 


\section{Wealth Status of Respondents}

\section{Type and Ownership Status of Housing and/number of Rooms Occupied}

Table 2 shows that $40 \%$ of the respondents were living in thatched mud house, $22 \%$ were living in hut, $21 \%$ in mud house with zinc while $16 \%$ were living in concrete house with Zinc. About $52 \%$ of the respondents were owner-occupiers, $29 \%$ were caretaker-occupiers and $19 \%$ were tenants in these houses. Also $56 \%$ of the respondents and their households lived in $1-2$ rooms, $34 \%$ occupied $3-4$ rooms and $9 \%$ occupied $5-6$ rooms. The mean number of rooms occupied by a respondent and his or her household was 2.7 rooms. It was obvious that most of the migrants were not living in luxury as floor space per capita was relatively small $\left(2.5 \mathrm{~m}^{2}\right)$.

\section{Farm tools Owned and Animals reared/owned}

Table 2 shows that $47 \%$ of the respondents had farm tools weighted $17-45$, $33 \%$ had farm tools weighted $46-74$, while $13 \%$ had tools weighted $75-103$. Also, majority $(72 \%)$ of the respondents had animals weighted $0-42,17 \%$ had animals weighted $43-84$.

\section{Total wealth status (number of tools and animals owned and type of housing)}

A composite wealth ranking based on number of tools and animals owned and type of housing was used to categorize the migrants into levels of well being. Fortyseven percent of the respondents were poor while $32 \%$ were very poor. Also $15 \%$ of the respondents were fairly secure, $4 \%$ were rich while the remaining $2 \%$ were very rich (Table 2). Majority $(79 \%)$ were poor, $15 \%$ of them were economically secured and only $6 \%$ of them were rich. This finding agrees with the fact that rural areas remain disadvantaged, their inhabitants maintain a marginalized existence while life there is characterized by abject poverty (Ezeani, 1995). 
TABLE 2: Distribution of respondents based on wealth status

\begin{tabular}{|c|c|c|c|}
\hline Wealth Status & Frequency & Percentage & Mean $(\bar{X})$ \\
\hline \multicolumn{4}{|l|}{ Type of housing } \\
\hline Hut & 22 & 22 & \\
\hline Thatched mud house & 40 & 40 & \\
\hline Mud house with zinc & 21 & 21 & \\
\hline Concrete house with zinc & 16 & 16 & \\
\hline Painted zinc/concrete house & 1 & 1 & \\
\hline \multicolumn{4}{|l|}{ Ownership Status of housing } \\
\hline Landlord & 52 & 52 & \\
\hline Caretaker & 29 & 29 & \\
\hline Tenant & 19 & 19 & \\
\hline \multicolumn{4}{|l|}{ Number of rooms occupied } \\
\hline $1-2$ & 56 & 56 & \\
\hline $3-4$ & 34 & 34 & 2.7 \\
\hline $5-6$ & 9 & 9 & \\
\hline $7-8$ & 1 & 1 & \\
\hline \multicolumn{4}{|l|}{ Farm tools owned } \\
\hline $17-45$ & 47 & 47 & \\
\hline $46-74$ & 33 & 33 & \\
\hline $75-103$ & 13 & 13 & \\
\hline $104-132$ & 5 & 5 & \\
\hline $133-161$ & 2 & 2 & \\
\hline \multicolumn{4}{|l|}{ Animals reared/owned } \\
\hline $0-42$ & 72 & 72 & \\
\hline $43-84$ & 17 & 17 & \\
\hline $85-126$ & 8 & 8 & \\
\hline $127-168$ & 1 & 1 & \\
\hline \multirow{2}{*}{\multicolumn{4}{|c|}{ Total Wealth status }} \\
\hline & & & \\
\hline $19-70$ & 32 & 32 & \\
\hline $71-122$ & 47 & 47 & \\
\hline $123-174$ & 15 & 15 & \\
\hline $175-226$ & 4 & 4 & \\
\hline $227-278$ & 2 & 2 & \\
\hline
\end{tabular}

\section{Agricultural Activities of Respondents}

\section{Major and minor crops grown by respondents}

Table 3 shows that majority ( $79 \%$ ) of the respondents grew yam as their major crop, $78 \%$ of them grew cassava while $68 \%$ of them grew cocoyam as major crop. Other major crops grown by the respondents were maize $(48 \%)$, pepper $(18 \%)$ and tomatoes (6\%). Also $45 \%$ of the respondents grew pepper as their minor crop, $37 \%$ grew tomatoes, $27 \%$ grew maize, while another $27 \%$ grew okro as a minor crop. These findings show that the migrant farmers produce mainly root crops as their major crops. This may be because root and tuber crops are among the most important group 
Journal of Agricultural Extension

Vol. 12 (2) December, 2008

of staple foods and are the largest source of calorie for the Nigerian population (Olaniyan et al., 2001).

TABLE 3: Distribution of the respondents by crops grown

\begin{tabular}{lcccc}
\hline *Crops Grown & $\begin{array}{l}\text { Frequency } \\
\text { Percentage }\end{array}$ & Percentage (\%) & \multicolumn{2}{c}{ Frequency } \\
\hline Types of crops & Major & Major & Minor & Minor \\
Yam & 79 & 79 & 10 & 10 \\
Cassava & 78 & 78 & 8 & 8 \\
Cocoyam & 68 & 68 & 19 & 19 \\
Maize & 48 & 48 & 27 & 27 \\
Groundnut & 4 & 4 & 25 & 25 \\
Pigeon pea & 2 & 2 & 1 & 1 \\
Rice & 2 & 2 & 7 & 7 \\
Okro & 2 & 2 & 27 & 27 \\
Tomatoes & 6 & 6 & 37 & 37 \\
Pepper & 18 & 18 & 45 & 45 \\
Leafy vegetables & 4 & 4 & 26 & 26 \\
Potato & 2 & 2 & 2 & 2 \\
Plantain/banana & 3 & 3 & 1 & 1 \\
\hline
\end{tabular}

*Multiple responses

\section{Agricultural Tasks of Migrant Men and Women Farmers in Destination Area}

Table 4 shows that migrant men farmers participated in various agricultural activities in the destination area. The agricultural activities that migrant men farmers participated most in were mound and ridge making $(\bar{X}=2.97)$, procurement of land for farming $(\bar{X}=2.94)$ and land clearing with hoe or knife $(\bar{X}=2.88)$. Other agricultural/farming activities with high mean scores were staking $(\bar{X}=2.39)$, harvesting $(\bar{X}=2.12)$, land clearing by bush burning $(\bar{X}=2.12)$ and transportation of planting materials to the farm $(\bar{X}=1.85)$. This finding is in line with what is common in many farm families particularly in Igboland, where activities like land clearing, cultivation, staking, harvesting of some crops, procurement of land for farming etc, are exclusively men's activities because they require much strength.

Table 4 also shows that migrant women farmers participated in various agricultural/farming activities in the destination area. The agricultural/farming activities that migrant women farmers participated in include weeding $(\bar{X}=2.61)$, transferring plants from nursery to the farm $(\bar{X}=2.11)$ and processing activities $(\bar{X}=2.10)$. Other agricultural/farming activities with high mean scores were nursery making $(\bar{X}=1.93)$, 
thinning $(\bar{X}=1.90)$, marketing activities $(\bar{X}=1.87)$, planting of seeds or stems $(\bar{X}=$ $1.8)$ and transportation of planting materials to the farm $(\bar{X}=1.57)$. This finding is in accordance with Amalu (1998), who observed that women are the controllers of post harvest activities such as food storage, processing and preservation.

TABLE 4: Mean scores of agricultural activities performed by migrant men and women farmers

\begin{tabular}{lcccc}
\hline Agricultural/farming Activities & \multicolumn{3}{c}{ Men } & Women \\
\cline { 2 - 5 } & $\begin{array}{c}\text { Mean } \\
\text { Score }\end{array}$ & $\begin{array}{c}\text { Standard } \\
\text { deviation }\end{array}$ & $\begin{array}{c}\text { Mean } \\
\text { Score }\end{array}$ & $\begin{array}{c}\text { Standard } \\
\text { deviation }\end{array}$ \\
\hline Mound and ridge making & 2.97 & 0.17 & 0.31 & 0.58 \\
Procurement of land for farming & 2.94 & 0.28 & 0.16 & 0.04 \\
Land clearing with hoe or knife & 2.88 & 0.43 & 0.33 & 0.62 \\
Staking & 2.39 & 0.92 & 0.42 & 0.75 \\
Harvesting & 2.12 & 0.79 & 1.32 & 0.72 \\
Land clearing by bush burning & 2.12 & 0.90 & 0.71 & 0.77 \\
Transportation of planting materials to & 1.85 & 1.01 & 1.57 & 0.78 \\
the farm & & & & \\
Transportation of products after & 1.40 & 0.75 & 1.79 & 0.80 \\
harvest from farm to home & & & & \\
Nursery making & 1.30 & 0.01 & 1.93 & 1.09 \\
Storage activities & 1.21 & 0.70 & 1.71 & 0.77 \\
Planting of the seeds and stems & 1.17 & 0.62 & 1.80 & 0.94 \\
Transferring nursery to the farm & 1.16 & 1.00 & 2.11 & 1.07 \\
Marketing activities & 1.14 & 0.59 & 1.87 & 0.65 \\
Thinning & 0.83 & 0.88 & 1.90 & 1.21 \\
Processing activities & 0.80 & 0.62 & 2.10 & 0.75 \\
Weeding & 0.40 & 0.71 & 2.61 & 0.71 \\
\hline
\end{tabular}

Differences in Agricultural Activities engaged in by Migrant Men and Women Farmers in the Destination Area.

Data in Table 5 show the t-values of agricultural activities performed by migrant men and women farmers in the destination area. The results of the analysis show that there were significant differences in the means of each of the various agricultural/farming activities performed on the basis of gender: procurement of land for farming $(\mathrm{t}=-55.23)$; land clearing with hoe/knife $(\mathrm{t}=33.70)$; land clearing by bush burning $(\mathrm{t}=-11.89)$; mound and ridge making $(\mathrm{t}=-43.93)$; transportation of planting materials to the farm ( $t=-2.19)$; planting of seeds and stems ( $t=5.58)$; nursery making $(\mathrm{t}=4.23)$; transferring nursery to the farm $(\mathrm{t}=6.47)$; weeding $(\mathrm{t}=22.01)$; 
thinning $(\mathrm{t}=7.16)$; staking $(\mathrm{t}=-16.56)$; harvesting $(\mathrm{t}=-7.44)$; transportation of products after harvest from farm to home $(t=3.59)$; processing activities $(t=13.41)$; storage activities $(t=4.81)$ and marketing activities $(t=8.37)$. This shows that agricultural/farming activities were gender stereotyped in the destination area. This may be because traditionally, farm tasks are gender-stereotyped ensuring that certain tasks performed by men are not performed by women in Igbo society. The implication is that these cultural traits are transferred into the destination areas. Extension therefore must take cognizance of such characteristics in dealing with migrant farmers.

TABLE 5: Distribution of respondents by agricultural activities performed by migrant men and women farmers

\begin{tabular}{lccc}
\hline Agricultural/farming activities & Men $(\bar{X})$ & Women $(\bar{X})$ & T-value \\
\hline Procurement of land for farming & 2.94 & 0.16 & $-55.23^{*}$ \\
Land clearing with hoe/knife & 2.88 & 0.33 & $-33.70^{*}$ \\
Land clearing by bush burning & 2.12 & 0.71 & $-11.89^{*}$ \\
Mound and Ridge making & 2.97 & 0.31 & $-43.93^{*}$ \\
Transportation of planting materials to the & 1.85 & 1.57 & $-2.19^{*}$ \\
farm & & & \\
Planting of seeds and stems & 1.17 & 1.80 & $5.58^{*}$ \\
Nursery making & 1.30 & 1.93 & $4.23^{*}$ \\
Transferring nursery to the farm & 1.16 & 2.11 & $6.47^{*}$ \\
Weeding & 0.40 & 2.61 & $22.01^{*}$ \\
Thinning & 0.83 & 1.90 & $7.16^{*}$ \\
Staking & 2.39 & 0.42 & $-16.56^{*}$ \\
Harvesting & 2.12 & 1.32 & $-7.44^{*}$ \\
Transportation of products after harvest from & 1.40 & 1.79 & $3.59^{*}$ \\
farm to home & & & \\
Processing activities & 0.80 & 2.10 & $13.41^{*}$ \\
Storage activities & 1.21 & 1.71 & $4.81^{*}$ \\
Marketing activities & 1.14 & 1.87 & $8.37^{*}$ \\
\hline
\end{tabular}

*Significant at $P \leq 0.05$

\section{Existing contact between Agricultural Extension Workers and the Migrant Farmers}

Majority $(75 \%)$ of the respondents had no knowledge of the existence of agricultural extension personnel within the area (Table 6). Also, majority (93\%) of the respondents had not been visited by extension agents in the last one year, while only $7 \%$ had been visited once by the extension agent in the last one year. Again, majority $(96 \%)$ of the respondents were not visited with innovation packages while only $4 \%$ of 
them were visited with innovation packages by the extension agents. Similarly, $96 \%$ of the farmers claimed they had not received any technology from extension. Key technologies received from agricultural extension were fertilizer $(3 \%)$, insecticide $(3 \%)$ improved production method $(2 \%)$, herbicide $(1 \%)$, seed/seedlings $(1 \%)$, improved harvesting method (1\%) and improved storage method (1\%).

These findings show that agricultural extension has not made reasonable contribution to the lives and agricultural activities of the migrant farmers. In other words, although the migrants had attained a level of integration, it was possible that as strangers they were discriminated against as found in Nigerian societies which may deprive them these benefits.

TABLE 6: Contacts between agricultural extension workers and the migrant farmers

\begin{tabular}{lcc}
\hline \multicolumn{1}{c}{ Agricultural Extension Activities } & Frequency & Percentage \\
Knowledge about agricultural extension & 75 & 75 \\
Having no knowledge & 25 & 25 \\
Have knowledge & 7 & 7 \\
Number of extension contacts in the last one year & 93 & 93 \\
Once & & \\
None & 4 & 4 \\
Extension agents visit & 96 & 96 \\
Visit with innovation package & & \\
Visit without innovation package & 3 & 3 \\
Innovations received from agricultural extension* & 1 & 3 \\
Fertilizer & 3 & 1 \\
Herbicide & 1 & 2 \\
Insecticide & 2 & 1 \\
Seed/seeding & 1 & 1 \\
Improved production Method & 1 & 96 \\
Improve harvesting method & 96 & \\
Improved storage method & & \\
Nothing & & \\
\hline
\end{tabular}

*Multiple responses

\section{Conclusion and Implication for Extension Policy}

This study has revealed that majority of the Igbo migrant farmers found among Odolu/Igalamela people of Kogi State were poor and had little or no contact with the public extension service. Policy issue relevant to extension entails incorporating these migrants into the clientele of public extension service (state agricultural development programme $(A D P))$. This will emphasize non-discriminatory attitude in selecting contact farmers among all citizens and creation of awareness on their existence and functions. Extension should also be equipped with incentives and useful technologies to be handed over to these farmers. Again, extension agents should be regular in their visit so as to make their work relevant to the farmers. In line with this, extension should also target those crops that migrant farmers are producing and the agricultural tasks that are gender stereotyped among these migrants and put them into 
consideration in designing extension intervention programmes. This is to ensure effective transfer, utilization and desirable outcome of extension information and technologies.

\section{References}

Adepoju, A (1986). Rural Migration and Development in Nigeria. Department of Demography and Social Statistics, University of lle-Ife, Ile- Ife Nigeria.

Amalu, U. C. (1998). Agricultural Research and Extension Delivery Systems in SubSaharan African. Calabar: University of Calabar Press.

Benard, A. and Spencer, T. (1998). Encyclopedia of Social and Cultural Anthropology. London: T.J. Press.

Dasgupta, B. (1984). Labour Organization and the Rural Economy FAO, Rome.

Ekong, E. E. (1988). An Introduction to Rural Sociology. Ile-Ife: Jumak Publishers Limited.

Ezeani, E. A.; (1995). National planning and rural development in Nigeria. In: Eboh, E. C; Okoye, C. U. and Ayichi, D. (eds.) Rural Development in Nigeria: Concepts, Processes and Prospects. Enugu: Auto Century Publishing Company. Pp $54-$ 72.

Fadayomi, T. O. (1988). Rural Development and Migration in Nigeria: the Impact of the Eastern Zone of Bauchi State Agriculural Development Project. Ibadan: In Tech Printers Limited.

Food and Agriculture Organization (1998). African Agriculture: The Next 25 Years. FAO of the United Nation, Rome.

Grant; M. (1998). Strangers in our home: spatiality and locale of Monomatapa township Cruelo, Rhodesian. Canadian Journal of Africa Studies: 32(1): 32 61.

Hugo, G. J. (1998). Migration as a survival strategy: the family dimension of migration. Population, Distribution and Migration, 89 (12): 139 - 149.

Mkhwanazi, M.; Dlamini, S; Mahindi, C; Gule G; Tumkaya, N; and Okorie, A. (1993). Introduction to Demography. A Publication of the UMEPA/UNDESCO Supported Training Programme Demography, University of Swaziland: 79 138.

National Population Commission (1998). 1991 Population Census of the Federal Republic of Nigeria: Analytical Report at the National Level. Abuja, Nigeria.

Okojie, C. E. (1984). Female migrants in the urban market, Benin City Nigeria. Canadian Journal of African Studies, 18(3): 547 - 562.

Olaniyan, G. O., Manyony, V. M. and Oyewole, B. (2001). The dynamics of the root and tuber cropping systems in the middle belt of Nigeria. In: Akoroda, M. O. and Ngeve, J. M. (eds.). Proceedings of the Triennial Symposium of the International Society for Tropical Root Crops (ISTRC). Cotonou. Pp 75-81. 
Poats, S. V. and Feldstein, H. S. (1990). Conceptual framework for gender analysis in farming systems research and extension. In: Feldstein, H. S. and Poats, S. V. (eds.). Working Together: Gender Analysis in Agriculture. Kumarian Press . pp 7- 37.

United Nations (1995). International Migration: Policies and the Status of Female Migrants. United Nations, New York.

World Bank (2000), Voices of the Poor: Crying Out for Change. Oxford University Press, Washington, D.C. 